\title{
Analysis of Process Configurations for Bioethanol Production from Microalgal Biomass
}

\author{
Razif Harun ${ }^{1,2}$, Boyin Liu ${ }^{1}$ and Michael K. Danquah ${ }^{1}$ \\ ${ }^{1}$ Bio Engineering Laboratory, Department of Chemical Engineering, \\ Monash University, Victoria, \\ ${ }^{2}$ Department of Chemical and Environmental Engineering, \\ Universiti Putra Malaysia, Serdang, \\ ${ }^{1}$ Australia \\ ${ }^{2}$ Malaysia
}

\section{Introduction}

Fossil fuel depletion has become a great concern as the world population is increasing at an alarming rate. Current concerns such as global warming, depletion of fossil fuels and increasing price of petroleum-based fuels have forced the search for alternative and costeffective energy sources with lesser greenhouse gas emissions. Research into the development of renewable and sustainable fuels has recognised bioethanol as a viable alternative to fossil fuels, owing to its low toxicity, biodegradability, and the ability to effectively blend with gasoline without any engine modifications (Harun et al., 2009, 2010a).

The utilization of crops such as sugar cane, sorghum and corn are considered as traditional approaches for bioethanol production (Harun et al., 2010a). The use of such feedstock for bioethanol production competes in the limited agricultural logistics for food production thus escalating the "food versus fuel debate" (Harun et al., 2010b). There has been a considerable interest in the use of microalgal biomass to replace food-based feedstock for renewable transport fuel production. Microalgae are autotrophic photosynthetic organisms considered as the fastest growing plant species known (Wayman, 1996). They can tolerate a wide range of $\mathrm{pH}$ and temperature conditions in diverse habitats including freshwater and sea water (Harun et al., 2010b). Microalgae can store considerable amounts of carbohydrates in the form of starch/cellulose, glycogen, hexoses and pentoses that can be converted into fermentable sugars for bioethanol production via fermentation (Wayman, 1996). Table 1 shows the amount of carbohydrates in various species of microalgae.

Compared to existing edible feedstock, microalgae grow easily with or without soil and offer a very short harvesting cycle (1 10 days) (Harun et al., 2010a). Microalgae also have a high capacity of fixing $\mathrm{CO}_{2}$ via photosynthesis and other greenhouse gases, resulting in an overall reduction in the net gaseous emissions during the entire life cycle of the fuel (Wayman, 1996). Majority of the work reported in literature relies on straightforward sequential application of the production process involving pre-treatment of the biomass, hydrolysis, fermentation and product recovery. Simultaneous occurrences or a combination 
of these process steps could hugely impact on the process economics of bioethanol production from microalgae. Different process approaches including Separate Hydrolysis and Fermentation (SHF), Separate Hydrolysis and Co-Fermentation (SHCF), Simultaneous Saccharification and Fermentation (SSF), Simultaneous Saccharification and CoFermentation (SSCF), and Consolidated Bioprocessing (CBP).

\begin{tabular}{cc}
\hline Algae strains & $\begin{array}{c}\text { Carbohydrates } \\
\text { (\% dry wt) }\end{array}$ \\
\hline Scenedesmus obliquus & $10-17$ \\
Scenedesmus quadricauda & - \\
Scenedesmus dimorphus & $21-52$ \\
Chlamydomonas rheinhardii & 17 \\
Chlorella vulgaris & $12-17$ \\
Chlorella pyrenoidosa & 26 \\
Spirogyra sp. & $33-64$ \\
Dunaliella bioculata & 4 \\
Dunaliella salina & 32 \\
Euglena gracilis & $14-18$ \\
Prymnesium parvum & $25-33$ \\
Tetraselmis maculate & 15 \\
Porphyridium cruentum & $40-57$ \\
Spirulina platensis & $8-14$ \\
Spirulina maxima & $13-16$ \\
Synechoccus sp. & 15 \\
Anabaena cylindrical & $25-30$ \\
\hline
\end{tabular}

Table 1. Amount of carbohydrates from various species of microalgae on a dry matter basis (\%) (Becker, 1994)

\section{Pretreatment of biomass}

Biomass pretreatment is a crucial step as it breaks down the crystalline structure of cellulose and releases the fermentable sugars so that the hydrolysis of carbohydrate can be achieved more rapidly and with greater yields (Mosier et al., 2005). An appropriate pretreatment process can also prevent the formation of inhibitors to the subsequent hydrolysis and fermentation (Sun \& Cheng, 2002). However, the pretreatment process contributes significantly to the cost of production (Alvira et al., 2010). The main methods include physical treatment (such as milling and grinding), thermo-chemical pretreatment (such as steam explosion) and ammonia fibre explosion. Mechanical comminution can be a combination of chipping, milling and grinding. It aims to reduce the particle size of the biomass to attain a larger surface area for enzyme access. The desired final particle size determines the appropriate technique to apply. For example, chipping is used when 10$30 \mathrm{~mm}$ particle size is required whilst milling and grinding are for more fine particles $(0.2-$ $2 \mathrm{~mm}$ ) (Alvira et al., 2010). The higher energy cost of mechanical comminution especially for large-scale applications makes it an unattractive approach for pretreatment (Hendriks \& Zeeman, 2009). However, small lab-scale experiments routinely employ mechanical comminution for biomass pretreatment. 


\section{Hydrolysis}

Two main hydrolysis methods are widely used to produce monomeric sugar constituents required for fermentation. These include acid hydrolysis (with dilute and concentrated acids) and enzymatic hydrolysis (Saha et al., 2005). The acid pretreatment process dissolves the hemicellulosic component of the biomass and disassembles the cellulose into fermentable sugars which are accessible to enzymes (Wayman, 1996). The use of concentrated acid is limited owing to higher cost, corrosion of containment material, and the formation of inhibiting compounds (Sun \& Cheng, 2002). Dilute sulphuric acid is the most studied acid, and gives high hydrolysis yields (Mosier et al., 2005). It can be applied at 180 ${ }^{\circ} \mathrm{C}$ for a short period of time or at $120^{\circ} \mathrm{C}$ for 30-90 min in different types of reactors such as plug flow, batch, shrinking-bed and counter-current reactors (Sun \& Cheng, 2002). Harun et al., (2010a) investigated bioethanol production under varying conditions of reaction time, temperature, microalgae loading and acid concentration. It was found that the highest bioethanol yield occurred with $10 \mathrm{~g} / \mathrm{L}$ of microalgae, $3 \%(\mathrm{v} / \mathrm{v})$ of sulphuric acid at $160^{\circ} \mathrm{C}$ for $15 \mathrm{~min}$.

Enzymatic hydrolysis is the utilization of enzymes to release the fermentable sugars from the biomass. The process cost of enzymatic hydrolysis is lower than acid hydrolysis as it avoids containment corrosion and occurs under mild temperatures and $\mathrm{pH}$ (Sanchez et al., 2004). There are few literatures on the study of biological pretreatments of microalgal biomass. However, the advantages of biological pretreatment can be extrapolated from studies using lignocellulosic biomass, which also contains cellulosic and hemicellulosic materials. There is a wide range of bacteria and fungi that can produce cellulases for hydrolysis, but fungi are mostly used due to their less severe growth conditions and high growth rates (Sanchez et al., 2004). Several white-rot fungi have been reported to enhance the hydrolysis of lignocellulosic materials, such as Phanerochaete chrysosporium, Ceriporia lacerata, Cyathus stercolerus, Ceriporiopsis subvermispora, Pycnoporus cinnarbarinus and Pleurotus ostreaus (Kumar \& Wyman, 2009). A study on fungal pretreatment of wheat straw for 10 days showed an increase in the release of fermentable sugars and a reduction in the concentration of fermentation inhibitors (Kuhar et al., 2008). A study by Singh et al., (2008) on fungal pretreatment of sugarcane also showed an increased release of sugars.

\section{Fermentation}

One of the most successful microorganisms for bioethanol production is Saccharomyces cerevisiae (Wyman, 1996). Although the wild-type strain has a high bioethanol productivity and very tolerant to high ethanol concentrations and inhibitory compounds, it is unable to ferment pentoses (hemicelluloses) (Hahn-Hagerdal et al., 2007). Pichia stipitis, Candida shehatae and Pachysolan tannophilus are promising microbes that are capable of fermenting both hexoses and pentoses (Lin \& Tanaka, 2006). However, S. cerevisiae is still the most commercialized and dominated strains for bioethanol production (Lin \& Tanaka, 2006). The disadvantage of S. cerevisiae can be overcome by introducing genetic information of xylose reductase and xylitol dehydrogenase (Tomas-Pejo et al., 2008). Although the fermentation can be performed as a batch, fed batch or continuous process, most ethanol production industries use the batch mode (Tomas-Pejo et al., 2008). Similar to other biomass, the overall process flow diagram for bioethanol production from microalgae is shown in Fig. 1. 


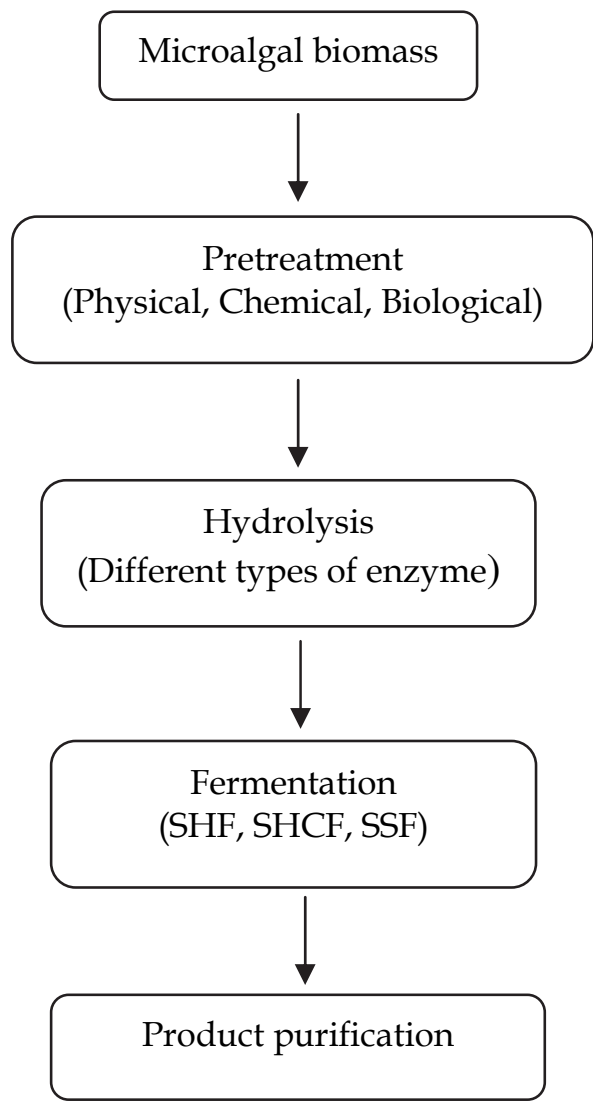

Fig. 1. The overall process flow diagram of bioethanol production from microalgal biomass.

\subsection{Separate Hydrolysis and Fermentation (SHF)}

In SHF, the enzymatic hydrolysis is performed separately from the fermentation step. Since hydrolysis and fermentation occur in separate vessels, each step can be performed at optimum conditions (Tomas-Pejo et al., 2008). More specifically, it enables enzymes to operate at optimum activities to produce more substrates for yeast fermentation. However, the accumulation of hydrolysis products leads to one of the drawbacks of SHF. Glucose and cellobiose inhibit the activities of the cellulases so the rate of hydrolysis is progressively reduced (Balat et al., 2008).

\subsection{Simultaneous Saccharification and Fermentation (SSF)}

SSF is an important process strategy for bioethanol production where the enzyme hydrolysis and fermentation are run in the same vessel. In contrast to SHF, the end-product inhibition from cellobiose and glucose in hydrolysis is progressively assimilated by the yeast in the fermentation process. Therefore, compared to SHF, the requirement for enzyme is lower and the bioethanol yield is higher in SSF (Lin \& Tanaka, 2006). Furthermore, the higher bioethanol concentration in SSF production also reduces foreign contamination 
(Chen \& Wang, 2010). Li et al., (2009) also increased the bioethanol yield of SSF by phosphoric acid-acetone pretreatment, which further reduced the inhibitory compounds in the hydrolysis and fermentation with a high solids content ( $>15 \%$ dry matter). Moreover, a fed-batch SSF system was adopted by Li et al., (2009) in order to overcome the problem. In the fed-batch operation, the cellulose suspension after pretreatment and hydrolysis is continuously fed to the bioreactor in order to maintain the liquid viscosity. The fed-batch system turned out to support bioethanol production. Since the hydrolysis and fermentation processes happen at a same temperature, finding an optimal temperature for SSF operation has become the most critical problem.

\subsection{Simultaneous Saccharification and Co-Fermentation (SSCF) \& Separate Hydrolysis and Co-Fermentation (SHCF)}

Microorganisms usually applied for bioethanol production cannot utilize all the sugar sources derived from hydrolysis. For example, the wild-type strain of $S$. cerevisiae is unable to use pentose, and this represents a waste of biomass and reduces the bioethanol yield. To overcome this problem, recombinant yeast or cellulosic enzyme cocktails are introduced during fermentation to convert a wide range of both hexoses and pentoses (Wyman, 1996). Therefore, SSCF can be considered as an improvement to SSF. The hydrolysis and fermentation steps are combined in one vessel for SSCF; hence it has the same characteristics as SSF, such as low cost, short process time, reduced contamination risk and less inhibitory effects (Chandel et al., 2007). A two-step SSCF has been proposed and studied by Jin et al., (2010), where the fermentation time is divided into two equal parts and same conditions were applied as in traditional SSCF. In the two-step SSCF, $4 \%$ of total cellulases were used in the first half of the fermentation process, and then the rest of the cellulases were introduced in the second half of the fermentation. The bioethanol yield increased by significantly improving the xylose consumption.

Another similar bioprocess is SHCF, which combines the advantages of SHF and SSCF. The hydrolysis and fermentation processes in SHCF take place in separate vessels so that each step can be performed at its optimal conditions. Besides, since the microbes utilize both pentoses and hexoses effectively in the co-fermentation process in SHCF, the bioethanol yield is higher than SHF. However, there is, to date, few literatures on SHCF operations, but the details can be deduced by referring to SHF and SSCF procedures.

\subsection{Consolidated Bioprocessing (CBP)}

CBP simultaneously combines biomass hydrolysis, utilization of liberated sugars and fermentation in one bioreactor ( $\mathrm{Xu}$ et al., 2010). Theoretically, CBP is energy efficient because of reduction of processes and is more cost effective than SSCF (Lynd et al., 2005). However, the crucial problem is to develop an organism to singularly combine all the features during the process. Among all the CBP potential microbes, thermophilic bacteria, such as Clostridium thermocellum, are believed feasible as they possess cellulolytic and ethanologenic characteristics under high temperature conditions (Georgieva et al., 2008). Complexes of cellulolytic enzymes contained in C. thermocellum known as cellulosome are responsible for cellulose degradation and sugar release. According to the finding from $\mathrm{Xu}$ et al., (2010), the temperature of $65^{\circ} \mathrm{C}$ was used with $\mathrm{pH}$ ranging from 6.5-7.4 to compromise between the optimal conditions of the growth of $C$. thermocellum and cellulosome activity. Table 2 shows a summary of the comparison between the different process configurations. 


\begin{tabular}{|c|c|c|}
\hline Process & Advantages & Disadvantages \\
\hline SHF & $\begin{array}{l}\text { Hydrolysis and fermentation take } \\
\text { place at optimum conditions }\end{array}$ & $\begin{array}{c}\text { Inhibitory effects } \\
\text { Increased contamination }\end{array}$ \\
\hline SSF & $\begin{array}{l}\text { Low quantity of enzyme input } \\
\text { High ethanol yield } \\
\text { Reduced foreign contamination } \\
\text { Less inhibitory effects } \\
\text { Lower cost }\end{array}$ & $\begin{array}{l}\text { Either hydrolysis or fermentation can be } \\
\text { performed under optimal conditions } \\
\text { Difficulty in process control }\end{array}$ \\
\hline SHCF & $\begin{array}{l}\text { High bioethanol yield } \\
\text { Hydrolysis and fermentation take } \\
\text { place at optimum conditions }\end{array}$ & $\begin{array}{l}\text { High enzyme load } \\
\text { Increased contamination risk } \\
\text { Inhibitory effects }\end{array}$ \\
\hline SSCF & $\begin{array}{l}\text { Shorter process time } \\
\text { High bioethanol yield } \\
\text { Less contamination risk }\end{array}$ & $\begin{array}{l}\text { High enzyme load } \\
\text { Either hydrolysis or fermentation can be } \\
\text { perform under optimal conditions }\end{array}$ \\
\hline СBP & $\begin{array}{l}\text { Cost effective } \\
\text { Energy efficient }\end{array}$ & $\begin{array}{l}\text { Lack of suitable organisms } \\
\text { Difficulty in process control }\end{array}$ \\
\hline
\end{tabular}

Table 2. Comparison of the different fermentation process configurations

\section{Experimental work}

To further understand the effects of different fermentation approaches on bioethanol production from microalgal biomass, experimental work was designed based on variations of some key process conditions such as the type of substrate, amount of biomass loading and the type of enzymes in order to investigate their influence on the production process. The details of the process are shown in Fig. 2.

\subsection{Strain and cultivation}

Chlorococcum sp. was grown in an outdoor bioreactor (100 L) located in Monash University, Victoria, Australia. The carbohydrate composition of the microalgae strain is shown in Table 3. The microscopic image of the strain is shown in Fig. 3. It was composed of $150.0 \mathrm{mg} / \mathrm{L}$ $\mathrm{NaNO}_{3}, 22.7 \mathrm{mg} / \mathrm{L} \mathrm{Na}_{2} \mathrm{SiO}_{3} .5 \mathrm{H}_{2} \mathrm{O}, 11.3 \mathrm{mg} / \mathrm{L} \mathrm{NaH} \mathrm{PO}_{4} .2 \mathrm{H}_{2} \mathrm{O}, 9.0 \mathrm{mg} / \mathrm{L} \mathrm{C}_{6} \mathrm{H}_{8} \mathrm{O}_{7} . x \mathrm{Fe}, 9.0$ $\mathrm{mg} / \mathrm{L} \mathrm{C}_{6} \mathrm{H}_{8} \mathrm{O}_{7}, 0.360 \mathrm{mg} / \mathrm{L} \mathrm{MnCl}_{2} .4 \mathrm{H}_{2} \mathrm{O}, 0.044 \mathrm{mg} / \mathrm{L} \mathrm{ZnSO} .7 \mathrm{H}_{2} \mathrm{O}, 0.022 \mathrm{mg} / \mathrm{L} \mathrm{CoCl} 2.6 \mathrm{H}_{2} \mathrm{O}$, $0.020 \mathrm{mg} / \mathrm{L} \mathrm{CuSO} \cdot 5 \mathrm{H}_{2} \mathrm{O}, 0.013 \mathrm{mg} / \mathrm{L} \mathrm{Na}_{2} \mathrm{MoO}_{4} \cdot 2 \mathrm{H}_{2} \mathrm{O}$, trace Vitamin $\mathrm{B}_{12}$, Biotin, and Thiamine. Modified $\mathrm{F}$ growth medium in synthetic seawater was used for cultivation. The bioreactor was aerated with compressed air to provide the needed $\mathrm{CO}_{2}$, while other cultivation parameters, such as reactor temperature and illumination level, were not controlled due to its outdoor location. The microalgal culture was dewatered by centrifugation (Heraeus, multifuge 3S-R, Germany) and dried overnight at $60^{\circ} \mathrm{C}$ in an oven (Model 400, Memmert, Germany). The dried biomass was homogenized by grinding in a laboratory disc miller (N.V Tema, Germany). 


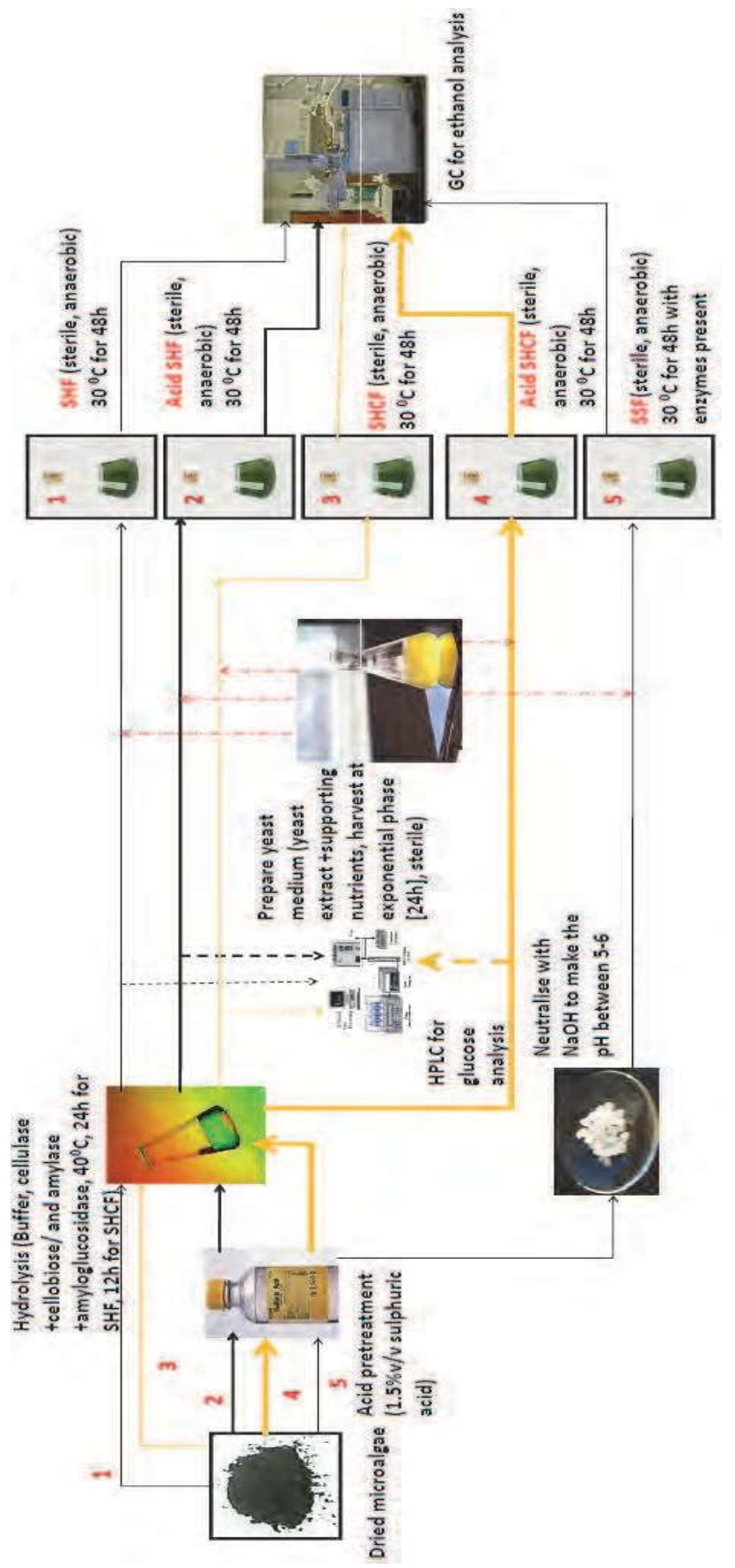

Fig. 2. A flow chart for the experimental procedure. 


\begin{tabular}{cc}
\hline Component & Composition $(\%, \mathrm{w} / \mathrm{w})$ \\
\hline Total carbohydrate & 32.52 \\
Xylose & 9.54 \\
Mannose & 4.87 \\
Glucose & 15.22 \\
Galactose & 2.89 \\
Starch & 11.32 \\
Others & 56.16 \\
\hline
\end{tabular}

Table 3. Composition of Chloroccum sp. [2]

\subsection{Enzymes}

The enzymes used in this study were cellulase from Trichoderma reesei (ATCC 26921), cellobiase from Aspergillus niger (Novozyme 188) and a-Amylase from Bacillus licheniformis, purchased from Sigma Aldrich, Australia. The activity of cellulase measured as 1.0 unit per mg solid means that one unit of cellulase liberates $1.0 \mu$ mole of glucose from cellulose in 1 hour at $\mathrm{pH}$ 5.0. Activities of cellobiase and a-amylase were 250 units/mg and 500 units/mg respectively.

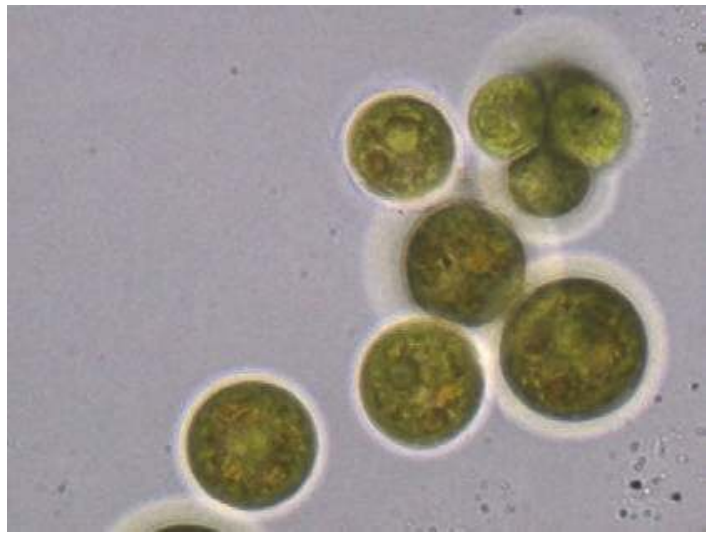

Fig. 3. The microscopic image of the microalgal cells before pretreatment. The images were taken at $40 \times$ magnification. The images show that microalgal cells have intact cell walls, thus pretreatment is required to rupture the cell wall to release fermentable sugars (Harun et al., 2010a)

\subsection{Fermentation process}

\subsubsection{Separate Hydrolysis and Fermentation (SHF)}

Two types of microalgal substrate were used in this study, acid pre-treated and untreated dried biomass. The acid pre-treated microalgal biomass was obtained after $1 \%(\mathrm{v} / \mathrm{v})$ sulphuric acid exposure at $140^{\circ} \mathrm{C}$ for $30 \mathrm{~min}$. The initial amounts of microalgae were varied from $25-100 \mathrm{~g} / \mathrm{l}$ with a constant mass of $20 \mathrm{mg}$ cellulase for hydrolysis. The enzymemicroalgal biomass mixtures were transferred into shake flasks containing $10 \mathrm{mM}$ of $100 \mathrm{~mL}$ sodium acetate buffer solution and incubated (LH Fermentation Ltd., Buckinghamshire, England) at $40{ }^{\circ} \mathrm{C}$, and $\mathrm{pH}$ of 4.8 for $24 \mathrm{~h}$. Samples were taken after every $5 \mathrm{~h}$ and 
immediately immersed in a hot water bath at temperature $\sim 90^{\circ} \mathrm{C}$ for $10 \mathrm{~min}$ in order to stop the enzymatic activity. The samples were then stored in a freezer at $-75{ }^{\circ} \mathrm{C}$ (Ultraflow freezer, Plymouth, USA) until further analysis.

For the fermentation process, Saccharomyces cerevisiae, purchased from Lalvin, Winequip Products Pty Ltd. (Victoria, Australia), was used for bioethanol production. The culture was prepared by dissolving $5.0 \mathrm{~g}$ of dry yeast powder in $50 \mathrm{ml}$ sterile warm water $\left(\sim 40^{\circ} \mathrm{C}\right)$ and the $\mathrm{pH}$ was adjusted to 7 by $1 \mathrm{M} \mathrm{NaOH}$. The yeast was cultured in YDP medium with composition in g/L given as follows: 10 yeast extract, 20 peptone, and 20 glucose. The yeast was harvested after $24 \mathrm{~h}$, washed to remove the sugars and then transferred into $500 \mathrm{~mL}$ Erlenmeyer flasks containing $100 \mathrm{~mL}$ of the sugar-containing liquid medium obtained after the hydrolysis process. The flasks were tightly sealed and nitrogen gas was bubbled through to create an oxygen-free environment for bioethanol production. The flasks were incubated at 30 ${ }^{\circ} \mathrm{C}$ under $200 \mathrm{rpm}$ shaking. The $\mathrm{pH}$ was maintained at 7 by adding $1 \mathrm{M} \mathrm{NaOH}$ solution. The fermentation process continued for $50 \mathrm{~h}$ and samples for analysis were taken after every $4 \mathrm{~h}$.

\subsubsection{Separate Hydrolysis and Co-Fermentation (SHCF)}

The procedures involved in hydrolysis and fermentation were conducted similarly to the SHF experiment, but the duration of hydrolysis was reduced to $12 \mathrm{~h}$.

\subsubsection{Simultaneous Saccharification and Fermentation (SSF)}

In the SSF experiment, different concentrations of microalgal biomass within the range 0.2$1.6 \% \mathrm{w} / \mathrm{w}$ were applied. The biomass was diluted using $1.5 \% \mathrm{w} / \mathrm{w}$ sulphuric acid and the slurry was autoclaved at $121^{\circ} \mathrm{C}$ for $30 \mathrm{~min}$ and then transferred into $500 \mathrm{ml}$ Erlmenyer flasks. Cellulase, cellobiase and yeast were aseptically added at $5 \%(\mathrm{w} / \mathrm{w}$ of microalgal biomass). The nutrients mixture, $5 \mathrm{~g} / \mathrm{L}$ yeast extract, $2 \mathrm{~g} / \mathrm{L}$ Ammonium chloride $\left(\mathrm{NH}_{4} \mathrm{Cl}\right), 1 \mathrm{~g} / \mathrm{L}$ Potassium phosphate $\left(\mathrm{KH}_{2} \mathrm{PO}_{4}\right)$, and $0.3 \mathrm{~g} / \mathrm{L}$ Magnesium sulphate $\left(\mathrm{MgSO}_{4}\right)$, were added to the solution. The flasks were placed in an incubator at $30^{\circ} \mathrm{C}$ and $200 \mathrm{rpm}$ for $50 \mathrm{hrs} .5 \mathrm{~mL}$ sample was taken after every 5 hours from each flask for analytical monitoring. a-amylase ( $5 \% \mathrm{w} / \mathrm{w}$ of microalgal biomass) was added to the solution in the second set of experiment in order to hydrolyse the starch present.

\subsection{Analytical procedures}

\subsubsection{Quantification of simple sugars}

Glucose concentration over time during the fermentation process was analysed using high pressure liquid chromatography (HPLC). The mobile phase used was a mixture of acetonitrile and water (85:15) at a flow rate of $1 \mathrm{~mL} / \mathrm{min} .30 \mu \mathrm{L}$ sample was injected at $50{ }^{\circ} \mathrm{C}$. The sample was filtered through a $13 \mathrm{~mm}$ membrane filter prior to injection. The glucose concentration was evaluated using a calibration curve generated from a HPLC-grade glucose.

\subsubsection{Quantification of bioethanol concentration}

The bioethanol concentration was analysed using gas chromatography (GC) (Model 7890A, Agilent, CA). The GC consists of an auto sampler, flame ion detector (FID) and HP-FFAP column, $50 \mathrm{~m} \times 0.20 \mathrm{~mm} \times 0.33 \mu \mathrm{m}$. The injector, detector and oven temperatures were maintained at 150,200 and $120^{\circ} \mathrm{C}$ respectively. Nitrogen gas was used as the carrier gas. The bioethanol concentration was quantified using a calibration curve prepared by injecting different concentrations of ethanol standard $(0.1-10 \% \mathrm{v} / \mathrm{v})$. 


\section{Results and discussion}

As shown in Fig. 4, it was generally observed that a lower concentration of biomass resulted in a higher bioethanol yield (g bioethanol/g biomass). This is partly due to enhanced interactions between available enzymes and the microalgal biomass. Also, high biomass concentrations could result in the production of inhibitors and toxins during the hydrolysis process, and this could retard the enzymatic activity. Therefore, the bigger inhibitory effect offset the advantage of biomass loading. Although SSF process does not have a separate hydrolysis stage, the enzymatic activity still affects the hydrolysis reaction which happened simultaneously with the fermentation.

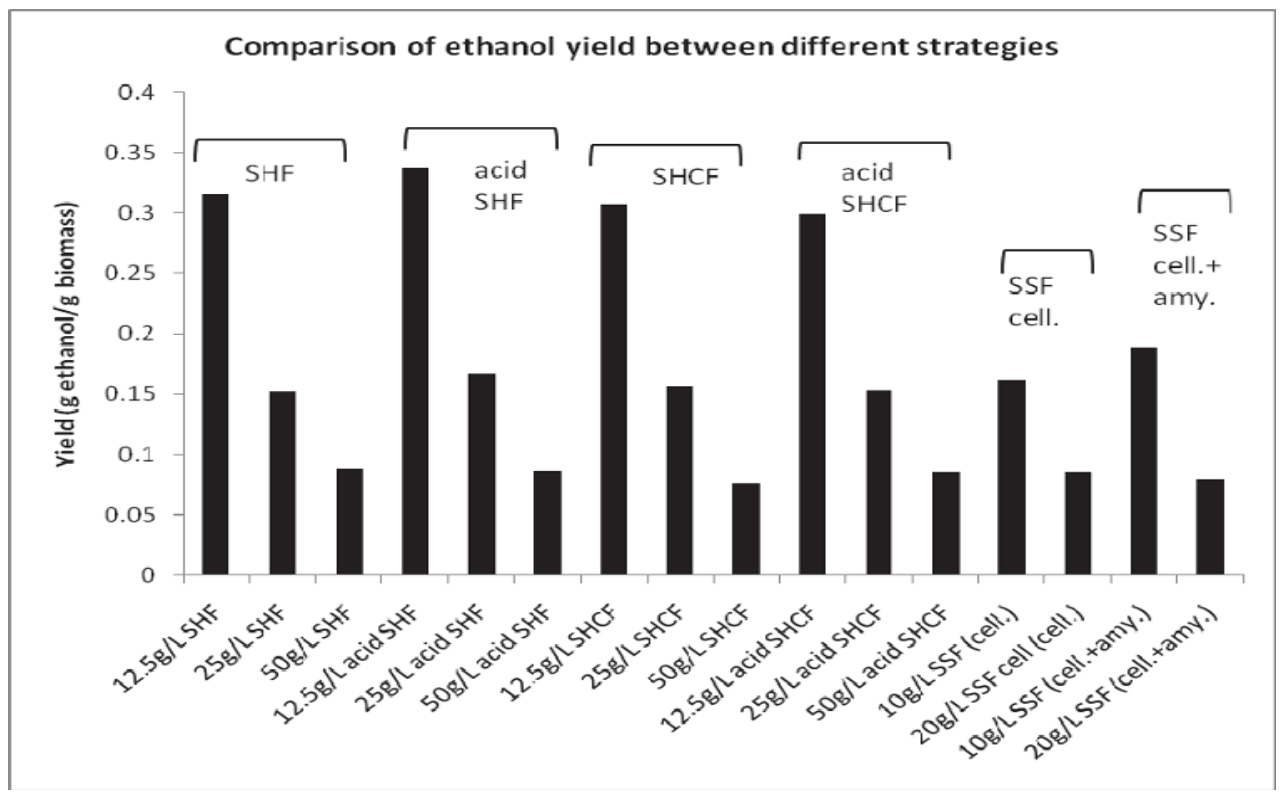

Fig. 4. Comparison of bioethanol yields for different process systems. All the fermentation processes were carried out at $30^{\circ} \mathrm{C}$ for $48 \mathrm{~h}$, with the $\mathrm{pH}$ maintained around 5-6 and a shaking speed of 200rpm

${ }^{*}$ cell. = cellulose+cellobiose; amy.= amylase+amyloglucosidase ${ }^{*} \mathrm{~g} / \mathrm{L}$ is the concentration of biomass

Overall, SHF generated the highest bioethanol yield and SSF the lowest, as shown in Fig. 4. It has been reported that SSF produces the highest bioethanol yield as it aims to reduce the contamination to the yeast by combining hydrolysis and fermentation into one step. However, due to inherent contamination during the anaerobic treatment, SSF did not achieve the desired yield. Furthermore, since hydrolysis and fermentation works at different temperatures, finding an optimal temperature for SSF is also a critical problem. Hence the unexpected lower yield from SSF could also be attributed to un-optimised temperature conditions. Another factor of influence is $\mathrm{pH}$. A slight change in $\mathrm{pH}$ from the optimum valu could cause a significant change in fermentation yields because yeast and the enzyme are sensitive to $\mathrm{pH}$. The performance of SHCF is slightly lower than SHF, possibly due to the 
shorter hydrolysis time. Therefore, theoretically, there was less monomeric sugar available for fermentation. Acid SHF process gave the highest yield among all the processes because the acid pretreatment step further disrupted the cell wall of the microalgae to release more fermentable sugars.

The SSF process with amylase and amyloglucosidase showed a significantly higher yield than the SSF process with only cellulase and cellobiase (Fig. 4). This is due to the hydrolysis of starch in the microalgae, which is $10 \%$ of the total mass, and the released sugars used for fermentation. However, the cost of enzymes will be a key parameter to consider against the increased bioethanol yield in a large-scale application.

Fig. 5 shows the glucose yield kinetics during the hydrolysis stage of SHF and SHCF. Glucose production progressively increased with time. Generally, SHF achieved higher yields than SHCF. This shows that the hydrolysis process requires an optimised duration at which the enzymatic activity is maximal. However, the main purpose of SHCF is cofermentation, where a genetically engineered strain is used so that both hexoses and pentose can be utilised, but in this study only the hydrolysis stage of SHCF was investigated. The glucose yield profile is also consistent with the bioethanol yield profile. Hydrolysate viscosity also has an influence on glucose yield; lower viscosity of the hydrolysate produces higher glucose yield due to enhanced molecular interactions between the enzyme and the substrate. Since SHF was performed for 24 hours and more cellulose and starch were hydrolyzed, the viscosity of SHF hydrolysate was lower.

Acid SHF process is supposed to produce more glucose because the acid pretreatment step disrupts the microalgal cell wall to release more fermentable sugars. However, Figure 6 shows the opposite. A possible reason is that the high acid concentration damaged the structure of some sugars, making them unavailable for fermentation. More work is required to explore the influence of high acid concentration on the released sugar.

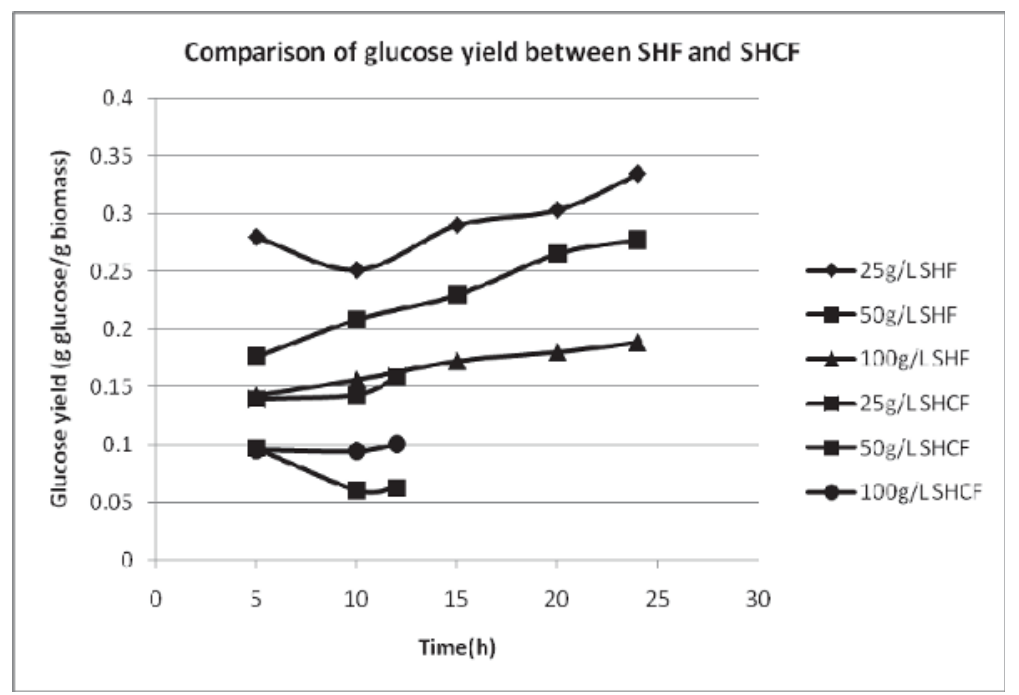

Fig. 5. Comparison of glucose yield between SHF and SHCF. All the hydrolysis processes were carried out at $40^{\circ} \mathrm{C}$ with a shaking speed of $200 \mathrm{rpm}$. The $\mathrm{pH}$ is maintained at 5 by sodium acetate/acetic acid buffer. SHF was run for $24 \mathrm{~h}$ while SHCF was only performed for $12 \mathrm{~h}$. 


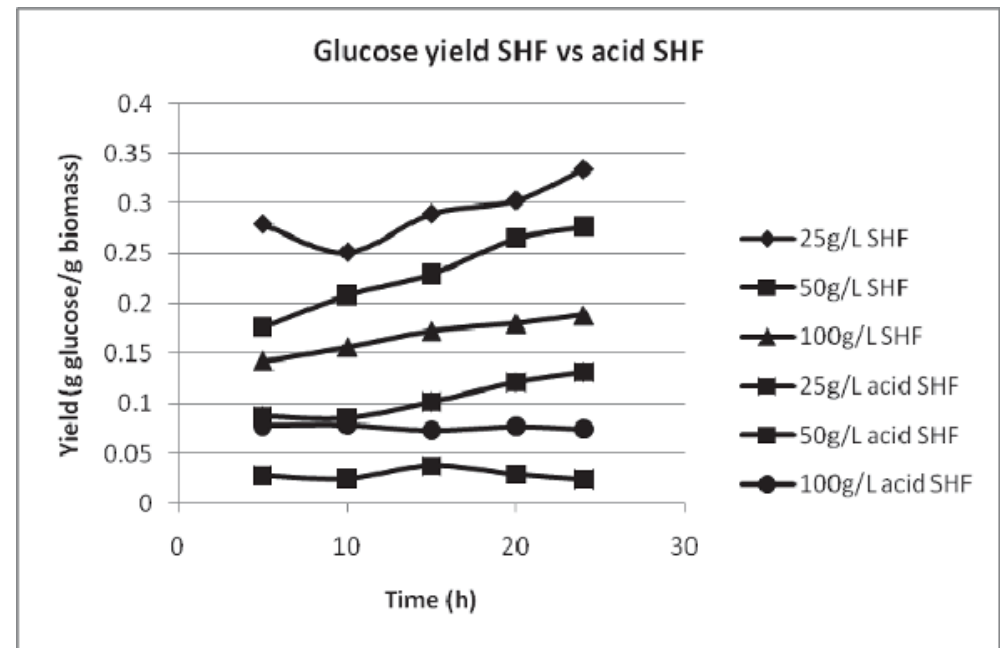

Fig. 6. Comparison of glucose yield between SHF and acid SHF. All the hydrolysis processes were carried out at $40^{\circ} \mathrm{C}$ for $24 \mathrm{~h}$ with a shaking speed of $200 \mathrm{rpm}$. The $\mathrm{pH}$ is maintained at 5 by sodium acetate/acetic acid buffer.

\section{Conclusions}

From the experimental results, it is concluded that acid SHF gave the best performance in terms of bioethanol production. However, there is a potential to improve on the yield of SSF. This could be done by reducing contaminations, applying optimum process conditions, and using genetic engineered yeast strains which can convert pentoses into bioethanol. In industrial applications, the cost of feedstock and cellulolytic enzymes are the two major parameters that contribute to the cost of production. About $40-60 \%$ of the total production cost is from raw materials. An integrated approach could improve the production economics; hence it is the main industrial option. Continuous fermentation often gives a higher productivity than batch fermentation. Besides, it reduces inhibitory effects and offers ease of control. Continuous process also keeps the microbes at the exponential phase hence raises the productivity significantly with shorter processing time.

\section{Acknowledgements}

This work has been supported by the Department of Chemical Engineering, Monash University, Australia and the Ministry of Higher Education, Malaysia.

\section{References}

Alvira, P.; Tomás-Pejó, E.; Ballesteros, M. \& Negro, MJ. (2010). Pretreatment technologies for an efficient bioethanol production process based on enzymatic hydrolysis: a review. Bioresource Technology, Vol. 101, No.13, (July 2010), pp. 4851-4861, ISSN 09608524 
Balat, M.; Balat, H. \& Oz, C. (2008). Progress in bioethanol processing. Progress in Energy and Combustion Science, Vol.34, No. 5, (October 2008), pp. 551-73, ISSN 03601285

Becker, EW. (1994). Microalgae: Biotechnology and Microbiology, Cambridge University Press, ISBN 0521350204, New York, USA

Chandel, AK.; Chan, ES.; Rudravaram, R.; Narasu, ML.; Rao, LV. \& Ravindra, P. (2007). Economics and environmental impact of bioethanol production technologies: an appraisal. Biotechnology and Molecular Biology Review, Vol.2, No.1, (February, 2007), pp. 14-32, ISSN 1538-2273

Chen, ML. \& Wang FS. (2010). Optimization of a fed-batch simultaneous saccharification and co-fermentation process from lignocellulose to ethanol. Industrial $\mathcal{E}$ Engineering Chemistry Research, Vol. 49, No.12, (Jun 2010), pp. 5775-5585, ISSN 08885885

Georgieva, TI.; Mikkelsen, MJ. \& Ahring, BK. (2008). Ethanol production from wet exploded Wheat straw hydrolysate by thermophilic anaerobic bacterium Thermoanaerobacter BG1L1 in a continuous immobilized reactor. Applied Biochemistry and Biotechnology, Vol.145, No. 1-3, (March 2008), pp. 99-110, ISSN 02732289

Harun, R.; Danquah, MK. \& Forde, GM. (2009). Microalgal biomass as a fermentation feedstock for bioethanol production. Journal of Chemical Technology \& Biotechnology, Vol. 85, No.2, (February 2010), pp. 199-203, ISSN 0268-2575

Harun, R. \& Danquah, MK. (2010a). Influence of acid pre-treatment on microalgal biomass for bioethanol production. Process Biochemistry, Vol.46, No.1, (January 2011), pp. 304-309, ISSN 13595113

Harun, R.; Singh, M.; Forde GM. \& Danquah MK. (2010b). Bioprocess engineering of microalgae to produce a variety of consumer products. Renewable and Sustainable Energy Reviews, Vol. 14, No.3, (April 2010), pp. 1037-1047, ISSN 13640321

Hahn-Hagerdal, B.; Karhumaa, K.; Fonseca, C.; Spencer-Martins, I. \& Gorwa-Grauslund, M. (2007). Towards industrial pentose-fermenting yeast strains. Applied Microbiology and Biotechnology, Vol.74, No.5, (April 2007), pp. 937-953, ISSN 01757598

Hendriks, ATWM. \& Zeeman, G. (2009). Pretreatments to enhance the digestibility of Lignocellulosic biomass. Bioresource Technology, Vol.100, No.1, (January 2009), pp.10-18, ISSN 09608524

Jin, M.; Lau, MW.; Balan, V. \& Dale, BE. (2010). Two-step SSCF to convert AFEX-treated switchgrass to ethanol using commercial enzymes and Saccharomyces cerevisiae 424A(LNH-ST). Bioresource Technology, Vol. 101, No. 21, (November 2010), pp. 8171-8178, ISSN 09608524

Kuhar, S.; Nair, LM. \& Kuhad, RC. (2008). Pretreatment of lignocellulosic material with fungi capable of higher lignin degradation and lower carbohydrate degradation improves substrate acid hydrolysis and eventual conversion to ethanol. Canadian Journal of Microbiology,Vol.54, No.4, (April 2008), pp. 305-313, ISSN 00084166

Kumar, R. \& Wyman, CE. (2009). Effects of cellulase and xylanase enzymes on the deconstruction of solids from pretreatment of poplar by leading technologies. Biotechnology Progress, Vol.25, No.2, (March 2009), pp. 302-314, ISSN 87567938

Li, H.; Kim, NJ.; Jiang, M.; Kang, JW. \& Chang, HN. (2009). Simultaneous saccharification and fermentation of lignocellulosic residues pretreated with phosphoric acidacetone for bioethanol production. Bioresource Technology, Vol.100, No.13, (July2009), pp. 3245-51, ISSN 09608524 
Lin, Y. \& Tanaka, S. (2006). Ethanol fermentation from biomass resources: current state and prospects. Applied Microbiology and Biotechnology, Vol.69, No.6, (February 2006), pp.627-642, ISSN 01757598

Lynd, LR.; van Zyl, WH.; McBride, JE. \& Laser, M. 2005. Consolidated bioprocessing of cellulosic biomass: an update. Current Opinion in Biotechnology, Vol.16, No.5, (October 2005), pp. 577-583, ISSN 09581669

Mosier, N.; Wyman, CE. ; Dale, BD. ; Elander, RT. ; Lee, YY. ; Holtzapple, M. \& Ladisch, CM. (2005). Features of promising technologies for pretreatment of lignocellulosic biomass. Bioresource Technology, Vol.96, No.6, (April 2005), pp. 673-86, ISSN 09608524

Saha, BC.; Iten, LB.; Cotta, MA. \& Wu, YV. (2005). Dilute acid pretreatment, enzymatic saccharification and fermentation of wheat straw to ethanol. Process Biochemistry, Vol. 40, No.12, (December 2005), pp. 3693-700, ISSN 13595113

Sanchez, G.; Pilcher, L.; Roslander, C.; Modig, T.; Galbe, M. \& Liden, G. (2004). Dilute acid hydrolysis for fermentation of the Bolivian straw material Paja Brava. Bioresource Technology, Vol.93, No.3, (July 2004), pp. 249-256, ISSN 09608524

Singh, P.; Suman, A.; Tiwari, P.; Arya, N.; Gaur, A. \& Shrivastava, AK. (2008). Biological pretreatment of sugarcane trash for its conversion to fermentable sugars. World Journal of Microbiology and Biotechnology, Vol.24, No.5, (May 2008), pp. 667-673, ISSN 09593993

Sun, Y. \& Cheng, J. (2002). Hydrolysis of lignocellulosic materials for ethanol production: a review. Bioresource Technology, Vol. 83, No.1, (2002), pp. 1-11, ISSN 09608524

Tomas-Pejo, E.; Oliva, JM.; Ballesteros, M. \& Olsson, L. (2008). Comparison of SHF and SSF processes from steam-exploded wheat straw for ethanol production by xylose fermenting and robust glucose-fermenting Saccharomyces cerevisiae strains. Biotechnology and Bioengineering, Vol.100, No.6, (August 2008), pp. 1122-1131, ISSN 00063592

Wayman, C. (1996). Handbook of Bioethanol: Production and Utilization, Taylor \& Fracis, ISBN 1-56032- 553-4, Washington, USA

Xu, C.; Qin, Y.; Li, Y.; Ji, Y.; Huang, J.; Song, H. \& Xu, J. (2010). Factors influencing cellulosome activity in Consolidated Bioprocessing of cellulosic ethanol. Bioresource Technology, Vol.101, No.24, (December 2010), pp. 9560-9, ISSN 09608524 


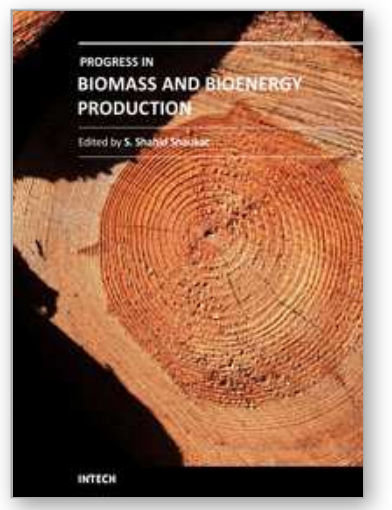

\author{
Progress in Biomass and Bioenergy Production \\ Edited by Dr. Shahid Shaukat
}

ISBN 978-953-307-491-7

Hard cover, 444 pages

Publisher InTech

Published online 27, July, 2011

Published in print edition July, 2011

Alternative energy sources have become a hot topic in recent years. The supply of fossil fuel, which provides about 95 percent of total energy demand today, will eventually run out in a few decades. By contrast, biomass and biofuel have the potential to become one of the major global primary energy source along with other alternate energy sources in the years to come. A wide variety of biomass conversion options with different performance characteristics exists. The goal of this book is to provide the readers with current state of art about biomass and bioenergy production and some other environmental technologies such as Wastewater treatment, Biosorption and Bio-economics. Organized around providing recent methodology, current state of modelling and techniques of parameter estimation in gasification process are presented at length. As such, this volume can be used by undergraduate and graduate students as a reference book and by the researchers and environmental engineers for reviewing the current state of knowledge on biomass and bioenergy production, biosorption and wastewater treatment.

\title{
How to reference
}

In order to correctly reference this scholarly work, feel free to copy and paste the following:

Michael Danquah, Boyin Liu and Razif Harun (2011). Analysis of process configurations for bioethanol production from microalgal biomass, Progress in Biomass and Bioenergy Production, Dr. Shahid Shaukat (Ed.), ISBN: 978-953-307-491-7, InTech, Available from: http://www.intechopen.com/books/progress-inbiomass-and-bioenergy-production/analysis-of-process-configurations-for-bioethanol-production-frommicroalgal-biomass

\section{INTECH}

open science | open minds

\section{InTech Europe}

University Campus STeP Ri

Slavka Krautzeka 83/A

51000 Rijeka, Croatia

Phone: +385 (51) 770447

Fax: +385 (51) 686166

www.intechopen.com

\section{InTech China}

Unit 405, Office Block, Hotel Equatorial Shanghai

No.65, Yan An Road (West), Shanghai, 200040, China 中国上海市延安西路65号上海国际贵都大饭店办公楼 405 单元

Phone: +86-21-62489820

Fax: +86-21-62489821 
(C) 2011 The Author(s). Licensee IntechOpen. This chapter is distributed under the terms of the Creative Commons Attribution-NonCommercialShareAlike-3.0 License, which permits use, distribution and reproduction for non-commercial purposes, provided the original is properly cited and derivative works building on this content are distributed under the same license. 